\title{
The Determinant of Acceptance of SIMDA (Information System of District Management) Implementation on the Government of Batu City
}

\author{
Umar Maksum \\ Zaki Baridwan \\ Imam Subekti \\ Universitas Brawijaya Malang \\ umar.maksum@yahoo.co.id
}

\begin{abstract}
This study aims to examine the factors influencing the acceptability of SIMDA in the Batu Municipal Government. The research model used the Technology Acceptance Model (TAM), which add external construct from D\&M success model of information system and other construct namely the commitment of management, social influence and the Individually influence such as computer selfefficacy and personal innovativenes. This research employed census sampling method. The samples are all official of in financial department who use SIMDA. Results of the research showed that perceived usefulness was affected by management commitment, social influence, information quality, system quality, personal innovativeness, and perceived ease of use. In addition, Computer selfefficacy, and personal innovativeness influenced to perceived ease of use. Furthermore, the acceptance SIMDA was influenced perceived usefulness and perceived ease of use. On the contrary, computer self-efficacy did not affect to perceived usefulness
\end{abstract}

Keywords: Technology Acceptance Model (TAM), Acceptance SIMDA, perceived usefulness, perceived ease of use

Abstrak: Penelitian ini bertujuan untuk menguji faktor yang memengaruhi keberterimaan pengguna SIMDA di Pemerintah Kota Batu. Model penelitian ini diadopsi dari TAM (Technology Acceptance Model) dengan menambahkan konstruk eksternal dari model kesuksesan sistem informasi DeLone dan Mclean berupa kualitas informasi dan kualitas sistem, serta konstruk lainnya yakni komitmen manajemen, pengaruh sosial dan pengaruh individul berupa keyakinan-sendiri komputer dan keinovatifan personal. Pengambilan sampel dilakukan dengan metode sensus (total sampling). Sampel adalah seluruh pegawai pengelola keuangan pengguna SIMDA. Hasil penelitian ini menunjukkan bahwa kegunaan persepsian dipengaruhi oleh komitmen manajemen, pengaruh sosial, kualitas informasi, kualitas sistem, keinovatifan personal, dan kemudahan penggunaan persepsian. Keyakinansendiri komputer, dan keinovatifan personal berpengaruh terhadap kemudahan penggunaan persepsian. Keberterimaan SIMDA dapat dipengaruhi oleh kegunaan persepsian dan kemudahan penggunaan persepsian. Namun, keyakinan-sendiri komputerterbukti secara empiris tidak berpengaruh terhadap kegunaan persepsian.

Kata Kunci: Technology Acceptance Model (TAM), keberterimaan SIMDA, kegunaan persepsian, kemudahan penggunaan persepsian

Pemerintah daerah sesuai dengan asas desentralisasi mempunyai kewajiban menyelenggarakan pemerintahan di daerah dengan melakukan pengelolaan keuangan daerah yang meliputi perencanaan, pelaksanaan, penatausahaan, pengawasan dan pelaporan keuangan daerah. Laporan keuangan pokok pemerintah daerah sesuai Standar Akuntansi Pemerintahan (SAP) pada Peraturan Pemerintah (PP) No.71 tahun 2010 terdiri atas: Laporan Realisasi Anggaran (LRA), Laporan Perubahan SAL (LPSAL), Laporan Operasi (LO), 
Laporan Perubahan Ekuitas (LPE), Laporan Arus Kas (LAK), Neraca dan Catatan atas Laporan Keuangan (CaLK).

Dengan berkembangnya teknologi informasi maka pemerintah daerah untuk mempermudah di dalam proses perencanaan, pelaksanaan dan penyusunan laporan keuangannya menggunakan aplikasi teknologi Sistem Informasi Akuntansi (SIA). Pemerintah Kota Batu menggunakan SIA dengan mengadopsi dari BPKP mulai tahun 2014 berupa SIMDA basis kas menuju akrual (cash towards accrual), SIMDA tersebut meliputi: SIMDA Keuangan, SIMDA Gaji dan SIMDA Pendapatan, dalam penulisan selanjutnya kami sebut SIMDA. SIMDA berbasis akrual diterapkan dikota Batu mulai tahun 2015 sebagai wujud implementasi PP No.71 tahun 2010 dan Permendagri No.64 tahun 2013 tentang penerapan SAP berbasis akrual pada pemerintah daerah.

Pengimplementasian sistem informasi merupakan suatu keputusan yang harus dipertimbangkan dengan baik oleh organisasi, karena harus menyediakan sejumlah dana yang besar. Tidak sedikit organisasi yang telah menginvestasikan dana yang besar di dalam SIA berbasis teknologi informasi akhirnya mengalami kegagalan karena tidak diterima dengan baik oleh pengguna. Pada tahun 2013 Pemerintah Kota Batu pernah mengimplementasikan SIA berbasis website tetapi mengalami kegagalan penggunaan, karena disebabkan kesulitan penggunaannya seperti: pengulangan memasukkan data keuangan dan membuat LRA, neraca lajur, dan neraca secara manual. Sehingga pada tahun 2014 Pemerintah Kota Batu beralih menggunakan SIMDA.

Permasalahan yang terjadi dalam pemanfaatan aplikasi SIMDA berbasis akrual di Pemkot Batu antara lain, yaitu: pertama, Implementasi yang relatif baru ini dimungkinkan akan memberikan tekanan bagi pengelola keuangan Satuan Kerja Perangkat Daerah (SKPD), seperti diketahui SDM dari pengelola keuangan hanya sekitar 10,7 \% yang berlatar belakang pendidikan akuntansi. Kedua, Adanya ketergantungan hanya kepada salah seorang dari pegawai di bidang pengelola keuangan, sehingga menghambat penyelesaian dan penyelenggaraan tugas SKPD yang pada akhirnya akan mempengaruhi kinerja dari pemerintah daerah. Ketiga tidak adanya pendampingan secara intensif sampai memahami penggunaan SIMDA bagi pengguna baru, misalnya untuk PPK-SKPD yang baru. Keempat, adanya permasalahan teknis yaitu ada beberapa akun pendapatan tidak bisa masuk ke jurnal akrual, sehingga tidak muncul di laporan keuangan yang berbasis akrual (LO, LPSAL, dan LPE). Kelima masih ada SKPD yang mengalami kesalahan input data ke SIMDA di dalam pertanggungjawaban uang panjar untuk mendapatkan Ganti Uang Panjar (GUP. Berawal dari berbagai permasalahan diatas, maka diperlukan sebuah pendekatan untuk menguji 
keberterimaan sistem informasi untuk mendorong efektifitas penggunaan sistem teknologi informasi.

Sistem teknologi informasi yang diadopsi oleh suatu organisasi atau institusi akan menimbulkan masalah keperilakuan (behavioral) karena adanya interaksi antara manusia dengan manusia dan manusia dengan sistem teknologi informasi maupun dengan organisasinya (Jogiyanto, 2008:2). Menurut Jogiyanto (2008:16) ada beberapa model dan teori sistem informasi keperilakuan yang dikembangkan dalam pemanfaatan ataupun adopsi teknologi informasi baru seperti model, salah satunya adalah model penerimaan teknologi (Technology Acceptance Model(TAM)) yang dikembangkan oleh Daviset. Al (1989).

TAM merupakan model keberterimaan sistem informasi yang sering digunakan dalam penelitian terhadap adopsi teknologi baru untuk memprediksi perilaku pengguna, namun beberapa peneliti juga mencoba mengembangkan model TAM dengan menambahkan beberapa variabel eksternal yang menerangkan lebih lanjut maupun menjadi penyebab (antecedent) dari varibel TAM yaitu: kegunaan persepsian (perceived usefullness), dan kemudahan penggunaan persepsian (perceived ease of use). Model TAM memempunyai beberapa kelebihan, antara lain: pertama, TAM merupakan model perilaku (behavior) yang dapat menjawab penyebab kegagalan/keberhasilan penerapan sistem informasi. Kedua, TAM dibangun dengan dasar teori psikologi yang cukup kuat. Ketiga, TAM merupakan model yang parsimoni (parsimonious) yaitu model yang sederhana tapi valid Jogiyanto (2008:134).

Penelitian ini mengadopsi model TAM dengan menambahkan beberapa faktor seperti: faktor institusional, faktor individual dan faktor sosial telah dikembangkan oleh Lewis et. al.(2003). Namun demikian Lewis et al. (2003) belum memasukkan faktor teknologi dan keberterimaan sistem informasi (acceptance IT) dalam penelitiannya. Jadi perbedaan antara penelitian Lewis et al. (2003) dengan penelitian ini adalah: pertama, penelitian ini menambahkan faktor teknologi yaitu kualitas informasi dan kualitas sistem yang diambil dari penelitiannya model kesuksesan sistem informasi DeLone dan McLean's (1992). Sehingga penelitian ini menggunakan empat faktor yaitu faktor institusional, faktor sosial, faktor teknologi dan faktor individual. Kedua, menambahkan konstruk keberterimaan sistem informasi (acceptance IT) untuk mengetahui keberterimaan dari penggunaan sistem informasi. Sedangkan penelitian di Indonesia dilakukan oleh Utama (2007), namun pada penelitian Utama (2007) tidak mengikutkan variabel kemudahan penggunaan persepsian (perceived ease of use) dan juga belum memasukkan faktor teknologi serta konstruk keberterimaan penggunaan sistem informasi. 
Menurut Lewis et. al. (2003) setiap institusi yang menggunakan sistem informasi berbasis teknologi tidak bisa lepas dari pengaruh faktor institusional berupa komitmen manajemen, faktor pengaruh sosial, dan faktor individual terdiri dari keyakinan-sendiri komputerdan keinovatifan personal. Faktor teknologimenurut Yusof et al. (2008) dilihat dari dua dimensi yaitu: kualitas sistem dan kualitas informasi yang dihasilkan.

Beberapa penelitian menunjukkan bahwa kegunaan persepsian dipengaruhi oleh komitmen manajemen, pengaruh sosial, kualitas informasi, kualitas sistem, computer self efficacy, keinovatifan personal dan kemudahan penggunaan persepsian. Begitu juga dengan konstruk kemudahan penggunaan persepsian dipengaruhi oleh konstruk computer self efficacy, keinovatifan personal. Pertama, penelitian Lewis et al. (2003) menunjukkan bahwa kepercayaan terhadap kegunaan teknologi (kegunaan persepsian) muncul dari dukungan organisasi (komitmen manajemen). Kedua, menurut Venkatesh dan Davis (2000) seseorang menggunakan opini dari pemberi referensi (pengaruh sosial) sebagai bagian dari struktur kepercayaannya dan kepercayaan-kepercayaan dari pemberi referensi ini menjadi kepercayaanya sendiri. Dengan demikian, pesan-pesan penting yang diterima dari orang lain akan mempengaruhi kognisi seseorang tentang kegunaan teknologi (kegunaan persepsian). Ketiga, penelitian Liu dan Arnett (2000) menyatakan bahwa informasi dengan kualitas terbaik (kualitas informasi) akan meningkatkan kegunaan persepsian pengguna dan meningkatkan penggunaan sistem informasi. Lin dan Lu (2000) juga menambahkan bahwa penerimaan atau penolakan pengguna atas sebuah sistem disebabkan oleh kualitas dari sistem informasi (kualitas sistem). Keempat, Setiap individu tentunya mempunyai karakteristik yang berbeda antara satu dengan yang lainnnya, sehingga akan memiliki kemampuan dan keinovatifan yang berbeda pula dalam melaksanakan pekerjannya, termasuk penerapan sistem informasi berbasis teknologi baru. Menurut Baridwan (2012) keinginan individu muncul karena pengguna percaya bahwa sistem informasi berbasis teknologi dapat membantu dirinya untuk mencapai kinerja yang baik (kegunaan persepsian) dan dirinya merasa mudah menggunakan sistem informasi (kemudahan penggunaan persepsian). Kelima, menurut Davis et al. (1989) jika seseorang percaya bahwa sistem teknologi informasi mudah digunakan (Kemudahan menggunakan persepsian), maka orang tersebut akan menggunakan sistem tersebut (kegunaan persepsian).

Keberterimaan SIMDA merupakan kecenderungan seseorang untuk menggunakan sistem dan merasa puas dengan sistem tersebut. Menurut Leksono (2015) seseorang yang memiliki persepsi bahwa sistem informasi mudah digunakan (kemudahan penggunaan persepsian) cenderung akan menganggap bahwa sistem informasi tersebut akan memberikan 
manfaat (kegunaan persepsian) dalam kehidupannya yang kemudian akan meningkatkan tingkat keberterimaannya.

Penelitian ini bertujuan untuk mengetahui tingkat keberterimaan pengelola keuangan satuan kerja dan faktor-faktor yang mempengaruhi, terkait penerapan SIMDA di Pemerintah Kota Batu.

\section{KAJIAN PUSTAKA}

\section{Faktor Institusional}

Peran faktor institusional dalam mempengaruhi individual dalam penggunaan teknologi informasi telah menjadi objek yang menarik dalam penelitian sistem informasi. Lewis et al. (2003) menunjukkan bahwa faktor institusioanal yang berpengaruh adalah dukungan dan komitmen dari manajemen dan juga digunakan oleh penelitian Yoon et al. (1995) dan Zmud (1984). Dalam penelitian Orlikowski (1992) faktor institusional disebut sebagai faktor organisasi.

Menurut Orlikowski (1992) faktor-faktor institusional yang mempengaruhi kognisi dan perilaku individual, yaitu proses signifikasi, legitimasi, dan dominasi. Signifikasi berarti individual-individual menggunakan informasi dari institusi untuk memahami bagaimana membentuk kepercayaan-kepercayaan teknologi baru yang diadopsi di dalam organisasi. Legitimasi berupa berita-berita dari manajemen puncak tentang legitimasi organisasional tentang kepercayaan-kepercayaan dan tindakan-tindakan. Dominasi menunjukkan situasi dimana organisasi meregulasi kepercayaan-kepercayaan individual (Jogiyanto, 1998).

\section{Pengaruh Sosial}

Beberapa konsep tentang pengaruh sosial telah banyak ditawarkan dalam literatur sistem informasi. Konsepsual yang dominan adalah yang ada pada teori TRA dan Theory of Planned Behavior (TPB) mengenai norma subjektif (subjective norm) yang didefinisikan sebagai tekanan sosial yang diperlukan untuk melakukan atau tidak melakukan perilaku (Ajzen, 1991).

Lewis et al. (2003) menggunakan konsepsualisasi pengaruh sosial berdasarkan atas konsep Fulk (1993) dan Schmitz dan Fulk (1991). Fulk (1993) berpendapat secara empiris menunjukkan bahwa seberapa penting orang-orang lain memandang penggunaan teknologi sebagai suatu yang bermanfaat dan mempunyai pengaruh positif pada persepsi seseorang mengenai kegunaanya. Dengan demikian, kolega sejawat, atasan, atau aktor sosial lain percaya bahwa teknologi sesuatu yang berguna, maka mereka menyebarkan melalui proses kognisi. 


\section{Keyakinan-Sendiri Kompuer (Computer Self-Efficacy)}

Computer Self-Efficacy diterjemahkan oleh Jogiyanto (2008) sebagai keyakinan-sendiri komputer. Keyakinan sendiri (Self Efficacy) didefinisikan oleh Bandura (1977) sebagai penilaian seseorang tentang kemampuan sendiri untuk melakukan tindakan yang diperlukan demi mencapai tujuanya. Hal ini tidak bersangkut dengan keterampilan seseorang tetapi mengenai anggapan tentang apa yang bisa dilakukan dengan keterampilan yang dimilikinya. Computer Self-Efficacy (CSE) didefinisikan oleh Compeau dan Higgins (1995) sebagai penilaian atas kemampuan/kapabiltas dan keahlian yang dimilki oleh individu untuk menggunakan komputer.

\section{Keinovatifan Personal}

Roggers (1995) mendefinisikan keinovatifan adalah sejauh mana individu atau lainnya relatif lebih awal dalam mengadopsi ide-ide baru dari suatu sistem. Dari definisi tersebut dapat dikatakan bahwa individu yang inovatif adalah jika mereka mengadopsi suatu keinovatifan lebih awal.

Menurut Agarwal dan Prasad (1998) bahwa individual-individual mengembangkan kepercayaan teknologi baru dengan mendapatkan informasi dari beberapa sumber seperti media masa dan hubungan personal. Individual-individual dengan keinovatifanya yang tinggi diharapkan mampu mengembangkan kepercayaan yang positif tentang teknologi. Agarwal dan Prasad (1998) mendefinisikan personal innovativeness (PI) dalam domain teknologi informasi, selanjutnya disebut PITT (PI in the domain of information technology), sebagai kesediaan individu untuk mencoba teknologi informasi baru.

\section{Kualitas Informasi}

Kualitas informasi untuk mengukur kualitas keluaran yang dihasilkan dari sistem informasi terutama dalam bentuk laporan (DeLone dan McLean, 1992). Ada beberapa bentuk pertanyaan untuk mengukur kualitas informasi, diantaranya dikembangkan oleh: Bailey dan Pearson (1983) adalah akurasi informasi (information accuracy), ketepatan waktuan keluaran (output timeliness), keandalan (reliability), kelengkapan (completeness), relevan (relevance), ketepatan (precision) dan kekinian (currency).

\section{Kualitas Sistem}

Kualitas sistem digunakan untuk mengukur kualitas teknologi sistem informasinya sendiri (DeLone dan McLean,1992). Pengukuran kualitas sistem yang dikembangkan oleh Bailey dan Pearson (1983) antara lain: fleksibilitas sistem (flexibility of the system), integrasi system (integration of the system), waktu respon/perubahan (response/turnarround time), 
perbaikan kesalahan (error recovery), kenyamanan akses (convinience of access) dan bahasa (language).

\section{Kegunaan Persepsian}

Kegunaan persepsian adalah sejauhmana seseorang mempercayai bahwa penggunaan teknologi dapat meningkatkan prestasi kerjanya (Davis, 1989). Menurut Dalcher dan Shine (2003) kegunaan persepsian merupakan kepercayaan yang dimiliki oleh seseorang terhadap penggunaan teknologi tertentu yang bisa meningkatkan kinerja mereka. Didasari dua definisi tersebut, maka dapat diambil kesimpulan bahwa kegunaan persepsian berkaitan dengan produktifitas dan efektifitas secara menyeluruh untuk meningkatkan kinerja pengguna sistem.

\section{Kemudahan Penggunaan Persepsian}

Kemudahan penggunaan persepsian yaitu sejauhmana seseorang percaya bahwa teknologi mudah untuk dipahami (Davis, 1989). Menurut Wibowo (2006) kemudahan penggunaan sebuah sistem informasi didefinisikan sebagai ukuran seseorang percaya teknologi tersebut mudah dipahami dan digunakan. Berdasarkan beberapa definisi diatas, bahwa kemudahan penggunaan dapat meminimalkan usaha seseorang baik tenaga maupun waktu untuk memahami sistem atau teknologi yang digunakan, karena pengguna meyakini sistem atau teknologi yang digunakan mudah untuk dipahami.

\section{Keberterimaan IT}

Keberterimaan penggunaan IT (Information Technology) didefinisikan oleh Swanson (1988) dalam Algahtani (2001) sebagai kecenderungan individu terhadap penggunaan sistem yang spesifik. Untuk mengetahui keberterimaan sistem teknologi informasi menurut Igbaria (1997) dan Algahtani (2001) para peneliti banyak yang mengukur konstruk penggunaan sistem (system use) dan kepuasan pengguna (user satisfaction). Menurut Davis et.al. (1989) penggunaan sistem adalah Actual use yang merupakan penggunaan sesungguhnya dari teknologi.

Menurut Jogiyanto (2007) user satisfaction merupakan respon penggunaan sistem terhadap keluaran sistem informasi. Pengukuran keberterimaan penggunaan dengan konstruk kepuasan pengguna dilakukan oleh Algahtani (2001), Mather et al. (2002), Armstrong et al. (2005), Ong et al. (2009), Rouibah (2009), Lai dan Pires (2010), Dai et al. (2011), Miyamoto et al. (2012) Bavarsad (2013).

\section{SIMDA (Sistem Informasi Manajemen Daerah)}

SIMDA dibuat oleh BPKP yang bertujuan untuk memfasilitasi dan mendukung pemerintah daerah untuk mempersiapkan aparatnya menghadapi perubahan, mendorong 
pelaksanaan tata kelola keuangan daerah sesuai dengan peraturan yang berlaku, efisien, efektif, transparan, akuntabel, dan auditabel.

Pemerintah Kota Batu menggunakan SIMDA Keuangan V 2.7 BPKP tahun 2015, yang merupakan modifikasi dari SIMDA versi 2.1, dikembangkan dalam rangka memenuhi kebutuhan implementasi basis akrual sesuai Standar Akuntansi Pemerintahan berdasarkan PP No.71 tahun 2010 dan Standar Akuntansi Pemerintahan Daerah berbasis akrual yang didasarkan pada Permendagri No.64 tahun 2013.

\section{Model Penelitian}

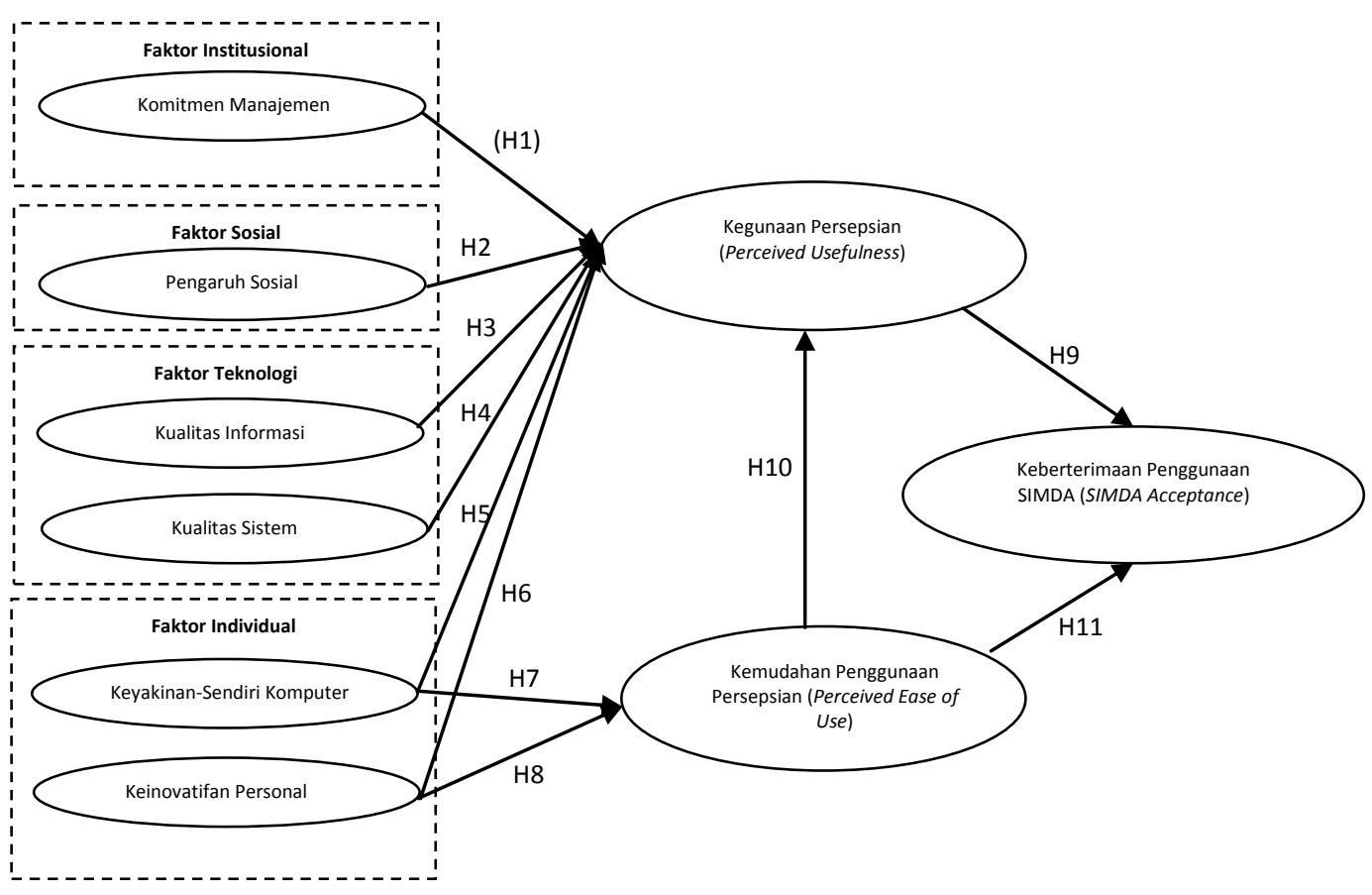

\section{Gambar 1. Model Penelitian}

\section{Hipotesis}

Berdasarkan model penelitian pada Gambar 1 ada 11 hipotesis untuk pengujian langsung dari H1 sampai H11 ditambah dengan dua hipotesis (yaitu H12 dan H13) untuk menguji efek mediasi atau pengujian tidak langsung, Hipotesis tersebut sebagai berikut:

H1: komitmen manajemen berpengaruh positif terhadap kegunaan persepsian (perceived usefulness)

H2: Pengaruh sosial berpengaruh positif terhadap kegunaan persepsian (Perceived Usefullness)

H3: Kualitas informasi berpengaruh positif terhadap kegunaan persepsian (perceived usefulness) 
H4: Kualitas sistem berpengaruh positif terhadap Kegunaan persepsian (perceived usefulness)

H5: Keyakinan-sendiri komputer(CSE) berpengaruh positif terhadap kegunaan persepsian sistem informasi (perceived usefulness)

H6: Personal Innovativeness(PI) berpengaruh positif terhadap kegunaan persepsian sistem informasi (perceived usefulness)

H7: Keyakinan-sendiri komputer $(C S E)$ berpengaruh positif terhadap kemudahan penggunaan sistem informasi

H8: Personal Innovativeness (PI) berpengaruh positif terhadap kemudahan penggunaan persepsian sistem informasi

H9: Kegunaan persepsian berpengaruh positif terhadap keberterimaan SIMDA

H10: Kemudahan penggunaan persepsian berpengaruh positif terhadap kegunaan persepsian SIMDA.

H11: Kemudahan penggunaan persepsian berpengaruh positif terhadap keberterimaan SIMDA.

H12: kegunaan persepsian memediasi pengaruh kemudahan penggunaan persepsian terhadap keberterimaan SIMDA

H13: kemudahan penggunaa persepsian memediasi pengaruh keinovatifan personal terhadap kegunaan persepsian

\section{METODE}

\section{Jenis Penelitian dan Metode Pengumpulan Data}

Pendekatan yang digunakan dalam penelitian ini adalah pendekatan kuantitatif dengan jenis penelitian korelasional. Data dikumpulkan dengan teknik survei atau lengkapnya selfadministered survey yaitu metode pengumpulan data primer dengan memberikan pertanyaanpertanyaan kepada responden (Jogiyanto, 2008). Data dikumpulkan dengan menggunakan instrumen penelitian berupa kuisioner.

\section{Unit analisis, Populasi dan Sampel Penelitian}

Unit analisis adalah individu, yaitu pejabat yang bertugas mengelola keuangan di satuan kerja perangkat daerah (SKPD) Kota Batu, Yaitu Bendahara Pengeluaran/Penerimaan, PPKSKPD (Pejabat Penatausahaan Keuangan-SKPD), dan Operator SIMDA. Populasi Penelitian ini ialah seluruh pejabat yang bertugas di bagian pengelola keuangan yang menggunakan SIMDA pada seluruh SKPD Pemerintah Kota Batu berjumlah 131 orang dari 41 SKPD yang 
terdiri dari: 6 badan, 12 dinas, 5 kantor, 8 bagian, 3 kecamatan, 5 kelurahan, Sekretariat DPRD, dan Inspektorat.

Karena jumlah populasi yang relatif kecil dan mudah dijangkau, maka seluruh anggota populasi dijadikan sampel. Metode pengambilan sampel dalam penelitian ini menggunakan seluruh anggota populasinya disebut dengan sampel total (total sampling) atau sensus.

\section{Metode Analisis}

Analisis data penelitian ini menggunakan metode statistik Structural Equation Model (SEM) berbasis varian dengan analisis Partial Least Square (PLS) dengan dibantu Aplikasi SmartPLS 2.0 M3.

\section{HASIL dan PEMBAHASAN}

\section{HASIL}

Kuesioner yang didistribusikan kembali $100 \%$ yaitu berjumlah 131 kuisioner. Kuesioner yang digunakan untuk analisis data sebanyak 121 kuisioner. Jadi ada 10 kuisioner yang dikeluarkan dari analisis karena diduga mengandung respon yang tidak serius berdasarkan pengecekan pada pernyataan negatif yang ada di dalam kuisioner.

Hasil statistik deskriptif dari jawaban responden untuk masing-masing konstruk penelitian yang ditunjukkan oleh Tabel 1, yaitu nilai terkecil (minimum), nilai terbesar (maksimum), nilai rata-rata (mean) dan standar deviasi. Hal ini untuk mengetahui sebaran jawaban responden terhadap item pertanyaan atau indikator tiap konstruk, sehingga bisa digunakan untuk mengetahui gambaran kesiapan maupun persepsi pengelola keuangan di SKPD Pemerintah Kota Batu terhadap implementasi SIMDA.

Tabel 1 Hasil Statistik Deskriptif

\begin{tabular}{lcccr}
\hline Konstruk & Minimum & Maksimum & Rata-rata & Standart Deviasi \\
\hline Komitmen Manajemen & 2 & 7 & 6,33 & 0,668 \\
Pengaruh Sosial & 3 & 7 & 6,15 & 0,728 \\
Kualitas Informasi & 2 & 7 & 5,92 & 0,795 \\
Kualitas Sistem & 1 & 7 & 5,75 & 0,950 \\
Keyakinan-sendiri komputer & 1 & 7 & 5,39 & 1,190 \\
Keinovatifan Personal & 1 & 7 & 5,21 & 1,351 \\
Kegunaan Persepsian & 2 & 7 & 6,06 & 0,688 \\
Kemudahan penggunaan & 2 & 7 & 5,71 & 0,865 \\
Keberterimaan SIMDA & 2 & 7 & 5,8 & 0,821 \\
\hline
\end{tabular}

Konstruk komitmen manajemen dengan 5 item pertanyaan, nilai rata-ratanya 6,33. Hampir sebagian responden setuju bahwa institusi tempat bekerja mendukung, mendorong dan menghargai penggunaan SIMDA dalam menyelesaikan tugas-tugas mereka. Bahkan responden sangat setuju dengan komitmen institusi menggunakan SIMDA dan penggunaan SIMDA sangat penting bagi Institusi. 
Nilai rata-rata untuk konstruk pengaruh sosial sebesar 6,15 , hal ini menunjukkan ratarata responden setuju bahwa terdapat dorongan atau pengaruh yang berasal dari sistem sosialnya untuk menggunakan SIMDA di dalam bekerja sehari-hari. Responden sangat setuju dengan adanya dorongan untuk mengunakan SIMDA yang berasal dari rekan kerja seprofesi dan juga rekan kerja mereka. Responden setuju bahwa terdapat dorongan dari kepala SKPD selaku pimpinan/atasan untuk menggunakan SIMDA di dalam bekerja. Hal ini berarti mereka berada di dalam posisi setuju bahwa terdapat dorongan dari luar diri mereka untuk menggunakan SIMDA dalam bekerja.

Konstruk kualitas informasi yang diwakili 5 item pertanyaan mendapatkan nilai ratarata 5,92. Hal ini menggambarkan bahwa responden cukup setuju bahwa kualitas informasi yang dihasilkan SIMDA telah sesuai dengan kebutuhan pekerjaan atau tugasnya sehari-hari. Berarti masih ada responden yang belum setuju sepenuhnya bahwa SIMDA yang diterapkan oleh Kantor SKPD mereka telah sesuai sepenuhnya dengan kebutuhan pekerjaan mereka. Namun demikian sebagian besar responden memandang bahwa SIMDA menghasilkan informasi yang akurat, dapat dipercaya, mudah dipahami dan sesuai dengan kebutuhan pekerjaan.

Responden setuju bahwa kualitas sistem SIMDA telah sesuai dengan kebutuhan pekerjaan atau tugasnya sehari-hari namun masih terbatas dalam pendapat cukup setuju. Hal ini terlihat dari rata-rata respon responden yang masih di Skala 5,75 yang berarti masih ada responden yang belum setuju sepenuhnya bahwa SIMDA yang diterapkan oleh Kantor SKPD mereka telah sesuai sepenuhnya dengan kebutuhan pekerjaan mereka.

Nilai mean sebesar 5,39 ditunjukkan oleh konstruk keyakinan-sendiri komputer, berarti responden menunjukkan pendapat cukup setuju bahwa diri mereka memiliki keyakinan diri bahwa diri mereka mampu menggunakan SIMDA yang digunakan di SKPD mereka. Hal ini juga menunjukkan masih ada pengguna SIMDA yang tidak terlalu yakin akan kemampuan diri mereka. Peneliti menyimpulkan bahwa, sebagian besar responden cukup setuju bahwa diri mereka mampu atau memiliki kemampuan untuk bisa menggunakan SIA berbasis TI di dalam pekerjaan mereka.

Berdasarkan nilai rata-rata konstruk keinovatifan personal bahwa diri mereka cukup setuju dengan keinovasian pada dirinya untuk mencoba suatu teknologi baru. Hal ini ditunjukkan nilai rata-rata responden sebesar 5,21 yang berarti responden masih cukup setuju bahwa diri mereka memiliki keinovasian di dalam TI. Hal ini menunjukkan bahwa masih ada responden yang belum terlalu yakin terhadap keinovasian diri mereka terhadap TI. 
Konstruk kegunaan persepsian mendapatkan nilai rata-rata 6,06, berarti responden memandang SIMDA yang digunakan di SKPD sebagai hal yang berguna. Hampir sebagian responden setuju bahwa SIMDA yang digunakan di kantornya bermanfaat bagi pekerjaan mereka sehari-hari dan meyakini bahwa SIMDA tersebut mampu meningkatkan performa, produktivitas dan efektivitas kerja mereka. Beberapa responden bahkan sangat setuju bahwa SIMDA yang digunakan di SKPD-nya adalah berguna bagi pekerjaannya.

Rata-rata responden memandang bahwa SIMDA yang digunakan di SKPD tidak terlalu mudah untuk digunakan di dalam pekerjaan mereka, hal ini dilihat dari hasil nilai mean sebesar 5,71. Responden memandang bahwa SIMDA yang digunakan di SKPD tidak terlalu mudah untuk dipelajari. Responden juga memandang bahwa SIMDA yang digunakan SKPD tidak terlalu mudah untuk digunakan hingga terampil. Maka dapat disimpulkan responden menganggap SIMDA tidak terlalu mudah untuk digunakan namun mereka masih mampu untuk menggunakannya untuk bekerja sehari-hari.

Rata-rata responden menunjukkan bahwa diri mereka menerima dan cukup puas menggunakan SIMDA yang digunakan di SKPD mereka. Hal ini dapat diketahui dengan melihat nilai mean dari konstruk keberterimaan SIMDA sebesar 5,8. Bila dilihat secara ratarata, responden cukup setuju (rata-rata respon responden ialah 5,8) bahwa diri mereka dapat menerima penggunaan SIMDA yang digunakan di kantor mereka saat ini.

Sebagian besar responden memberikan respon di skala 6 yang menunjukkan bahwa responden setuju bahwa diri mereka dapat menerima penggunaan SIMDA yang digunakan di kantor mereka untuk bekerja seterusnya. Berdasarkan frekuensi respon dari data kuesioner menunjukkan bahwa responden sangat setuju bahwa diri mereka puas dan menerima penggunaan SIMDA yang digunakan di kantornya sekarang.

Evaluasi dimulai dari model pengukuran berupauji validitas dan reliabilitas yang berguna untuk mengetahui apakah model pengukuran telah valid dan reliabel.

Tabel 2. Overview Hasil Algoritma PLS

\begin{tabular}{cccccccr}
\hline & AVE & $\begin{array}{c}\text { Composite } \\
\text { Reliability }\end{array}$ & $\begin{array}{c}\mathbf{R} \\
\text { Square }\end{array}$ & $\begin{array}{c}\text { Cronbachs } \\
\text { Alpha }\end{array}$ & $\begin{array}{c}\text { Communa } \\
\text { lity }\end{array}$ & $\begin{array}{c}\text { Akar } \\
\text { AVE }\end{array}$ & Korelasi \\
\hline CSE & 0,679397 & 0,863428 & & 0,764049 & 0,679397 & 0,834603 & 0,75381 \\
KI & 0,599817 & 0,882163 & & 0,830730 & 0,599817 & 0,774479 & 0,544182 \\
KM & 0,647934 & 0,901705 & & 0,865605 & 0,647933 & 0.804943 & 0,742338 \\
KP & 0,687031 & 0,867601 & & 0,780059 & 0,687031 & 0.828873 & 0,402431 \\
KS & 0,613134 & 0,904076 & & 0,872558 & 0,611340 & 0.783029 & 0,67614 \\
PEU & 0,677182 & 0,893200 & 0,546085 & 0,840193 & 0,677182 & 0,822911 & 0,735381 \\
PS & 0,741093 & 0,894868 & & 0,825561 & 0,741093 & 0,860868 & 0,742338 \\
PU & 0,697895 & 0,919789 & 0,509786 & 0,889605 & 0,697895 & 0,835401 & 0,588313 \\
SA & 0,696479 & 0,872404 & 0,557872 & 0,779960 & 0,696479 & 0,834553 & 0,70837 \\
\hline
\end{tabular}

Pada Tabel 2 memperlihatkan skor AVE dan communality seluruhnya sudah di atas 0,5 .

Nilai loading factor untuk sebagian besar indikator telah di atas 0,7. skor cronbach's alpha 
dan composite reliability di atas 0,7 . Dengan demikian, hasil ini menunjukkan bahwa seluruh konstruk telah lolos uji validitas dan uji reliabilitas.

Tabel 3 Hasil Pengujian Hipotesis Model Struktral

\begin{tabular}{|c|c|c|c|c|c|c|}
\hline Hipotesis & Konstruk & Pernyataan & $\begin{array}{c}\text { Koefisien } \\
\text { Jalur }\end{array}$ & $\begin{array}{c}\text { Standard } \\
\text { Error }\end{array}$ & T-Statistic & Keputusan \\
\hline H1 & $\mathrm{KM}->\mathrm{PU}$ & $\begin{array}{l}\text { komitmen manajemen } \\
\text { berpengaruh positif terhadap } \\
\text { kegunaan persepsian } \\
\text { (Perceived Usefulness) }\end{array}$ & 0,071339 & 0,040537 & 1,759838 & Diterima \\
\hline H2 & PS -> PU & $\begin{array}{l}\text { Pengaruh sosial berpengaruh } \\
\text { positif terhadap kegunaan } \\
\text { persepsian (Perceived } \\
\text { Usefullness) }\end{array}$ & 0,146317 & 0,045826 & 3,192891 & Diterima \\
\hline H3 & $\mathrm{KI} \rightarrow \mathrm{PU}$ & $\begin{array}{l}\text { Kualitas informasi } \\
\text { berpengaruh positif terhadap } \\
\text { kegunaan persepsian SIMDA }\end{array}$ & 0,234448 & 0,051604 & 4,53879 & Diterima \\
\hline H4 & $\mathrm{KS}->\mathrm{PU}$ & $\begin{array}{l}\text { Kualitas sistem berpengaruh } \\
\text { positif terhadap kegunaan } \\
\text { persepsian SIMDA }\end{array}$ & 0,169704 & 0,068720 & 2,469491 & Diterima \\
\hline H5 & CSE-> PU & $\begin{array}{l}\text { Keyakinan-sendiri } \\
\text { komputerberpengaruh positif } \\
\text { terhadap kegunaan persepsian } \\
\text { sistem informasi. }\end{array}$ & $-0,087196$ & 0,075016 & 1,162362 & Ditolak \\
\hline H6 & CSE->PEU & $\begin{array}{l}\text { Keyakinan-sendiri } \\
\text { komputerberpengaruh positif } \\
\text { terhadap kemudahan } \\
\text { penggunaan sistem informasi }\end{array}$ & 0,703379 & 0,039020 & 18,026205 & Diterima \\
\hline H7 & $\mathrm{KP}$-> PU & $\begin{array}{l}\text { Personal Innovativeness }(P I) \\
\text { berpengaruh positif terhadap } \\
\text { kegunaan persepsian sistem } \\
\text { informasi. }\end{array}$ & 0,156770 & 0,041942 & 3,737752 & Diterima \\
\hline H8 & KP -> PEU & $\begin{array}{l}\text { Personal Innovativeness }(P I) \\
\text { berpengaruh positif terhadap } \\
\text { kemudahan penggunaan } \\
\text { persepsian sistem informasi }\end{array}$ & 0,079523 & 0,036339 & 2,188358 & Diterima \\
\hline H9 & PU $\rightarrow$ SA & $\begin{array}{l}\text { Kegunaan persepsian } \\
\text { berpengaruh positif terhadap } \\
\text { keberterimaan SIMDA }\end{array}$ & 0,535967 & 0,047694 & 11,237521 & Diterima \\
\hline H10 & PEU -> PU & $\begin{array}{l}\text { Kemudahan penggunaan } \\
\text { persepsian berpengaruh } \\
\text { positif terhadap kegunaan } \\
\text { persepsian SIMDA. }\end{array}$ & 0,341607 & 0,06998 & 4,922432 & Diterima \\
\hline H11 & PEU -> SA & $\begin{array}{l}\text { Kemudahan penggunaan } \\
\text { persepsian berpengaruh } \\
\text { positif terhadap } \\
\text { keberterimaan SIMDA. }\end{array}$ & 0,292989 & 0,038455 & 7,619072 & Diterima \\
\hline
\end{tabular}

Selanjutnya dilakukan pengujian hipotesis untuk mengetahui tingkat signifikansi dan adanya pengaruh antar konstruk. Hipotesis dikatakan terdukung apabila nilai $T$-statistic lebih tinggi daripada nilai T-table. Hipotesis dalam penelitian ini adalah hipotesis 1 arah (one tailed), dengan alpha 5\% (tingkat keyakinan 95\%) sehingga hipotesis akan diterima/terdukung jika nilai T-statistic lebih besar atau sama dengan 1,64. Tabel 3 menunjukkan hasil pengujian hipotesis. 


\section{PEMBAHASAN}

Pengaruh konstruk komitmen manajemen terhadap kegunaan persepsian diuji melalui hipotesis H1. Hasil pengujian menunjukkan bahwa H1 diterima, hal ini menunjukkan komitmen manajemen mempunyai pengaruh positif terhadap kegunaan persepsian. Hal ini bermakna bahwa semakin tinggi komitmen dari SKPD di Pemerintah Kota Batu untuk memberikan dukungan kepada pengelola keuangan akan meningkatkan persepsi kemanfaatan penggunaan SIMDA. Sehingga pengelola keuangan akan terdorong menggunakan SIMDA dengan sebaik-baiknya.

Pengaruh Konstruk faktor sosial terhadap kegunaan persepsian diuji melalui Hipotesis H2. Hasil Pengujian menunjukkan bahwa H2 diterima dalam penelitian ini yang menunjukkan bahwa pengaruh sosial memiliki pengaruh terhadap kegunaan persepsian di 41 SKPD untuk menerima SIMDA di dalam pekerjaannya sehari-hari. Nilai koefesien jalur menunjukkan bahwa pengaruh sosial berpengaruh positif terhadap kegunaan, ini berarti semakin tinggi keyakin pengguna SIMDA bahwa sistem sosialnya mendorong dirinya untuk menggunakan SIMDA dalam pekerjaannya sehari-hari, maka persepsi atas kegunaan SIMDA akan semakin meningkat.

Pengaruh konstruk kualitas informasi terhadap kegunaan persepsian diuji melalui Hipotesis H3. Hasil Pengujian menunjukkan bahwa H3 diterima dalam penelitian ini yang menunjukkan bahwa kualitas informasi memiliki pengaruh terhadap kegunaan persepsian pada kantor SKPD untuk menerima SIMDA di dalam pekerjaannya sehari-hari. Hasil pengujian menunjukkan bahwa kualitas informasi berpengaruh positif terhadap kegunaan persepsian, yang bermakna semakin tinggi kualitas informasi yang dihasikan dari teknologi yang digunakan mampu meningkatkan persepsi kemanfaatan SIMDA tersebut untuk terus melanjutkan penggunaannya.

Pengaruh konstruk kualitas sistem terhadap kegunaan persepsian diuji melalui Hipotesis H4. Hasil Pengujian menunjukkan bahwa H4 diterima dalam penelitian ini yang menunjukkan bahwa kualitas sistem memiliki pengaruh terhadap kegunaan persepsian untuk menerima SIMDA di dalam pekerjaannya sehari-hari. Hasil pengujian menunjukkan bahwa kualitas sistem berpengaruh positif terhadap kegunaan persepsian, hal ini berarti semakin tinggi kualitas sistem dari teknologi yang digunakan untuk pekerjaanya mampu meningkatkan persepsi kemanfaatan SIMDA.

Pengaruh keyakinan-sendiri komputerterhadap kegunaan persepsian (persepsi kemanfaatan) SIMDA diuji melalui Hipotesis H5. Hasil pengujian menunjukkan bahwa H5 ditolak dalam penelitian ini yang menunjukkan bahwa keyakinan-sendiri komputertidak 
memiliki pengaruh terhadap kegunaan persepsian SIMDA di dalam pekerjaannya sehari-hari. Hasil pengujian menunjukkan bahwa tidak terdapat cukup bukti empiris untuk mengatakan bahwa konstruk keyakinan-sendiri komputer memiliki pengaruh terhadap persepsi kemanfaatan penggunaan SIMDA yang muncul dari diri sendiri. Persepsi kemanfaatan implementasi SIMDA tidak dipengaruhi oleh responden sendiri, hal ini dimungkinkan karena para pengguna SIMDA yaitu pengelola keuangan di Pemkot Batu sudah merasa jelas kemanfaatan penggunaan SIMDA sehingga tidak lagi memerlukan pertimbangan dari keyakinan diri (computer self-efficacy) untuk menggunakannya. Kejelasan kegunaan dan manfaat dari SIMDA bagi pengelola keuangan Pemkot Batu sudah banyak dipaparkan waktu sosialisasi dan workshop SIMDA berbasis akrual maupun diskusi dengan sesama pengelola keuangan. Kejelasan manfaat ini akan mengurangi pengaruh persepsi sendiri mengenai kemampuannya pada kepercayaan kegunaan SIMDA.

Pengaruh konstruk keinovatifan personal terhadap kegunaan persepsian (persepsi manfaat) SIMDA diuji melalui Hipotesis H6. Hasil Pengujian H6 diterima, yang menunjukkan bahwa konstruk keinovatifan personal berpengaruh terhadap kegunaan persepsian (persepsi manfaat) SIMDA yang digunakan dalam pekerjaan sehari-hari. Hasil pengujian menunjukkan bahwa keinovatifan personal berpengaruh positif terhadap kegunaan persepsian, ini berarti bahwa semakin tinggi perilaku inovatif pengelola keuangan di Pemerintah Kota Batu maka semakin mampu seseorang untuk menggunakan cara alternatif dan lebih memahami kegunaan SIMDA untuk membantu pekerjaannya.

Pengaruh konstruk keyakinan-sendiri komputer terhadap kemudahan penggunaan persepsian (persepsi kemudahan penggunaan) SIMDA diuji melalui Hipotesis H7. Hasil pengujian menunjukkan bahwa $\mathrm{H} 7$ diterima dalam penelitian ini yang menunjukkan bahwa keyakinan-sendiri komputer memiliki pengaruh terhadap kemudahan penggunaan persepsian (persepsi kemudahan menggunakan) SIMDA di dalam pekerjaannya sehari-hari. Hasil pengujian ini menunjukkan bahwa keyakinan-sendiri komputer berpengaruh positif terhadap kemudahan penggunaan persepsian, ini berarti semakin tinggi kemampuan diri dari pengelola keuangan di Pemerintah Kota Batu untuk menggunakan SIMDA dalam pekerjaannya akan meningkatkan persepsi kemudahan menggunakan menggunakan SIMDA tersebut.

Pengaruh konstruk keinovatifan personal terhadap kemudahan penggunaan persepsian (persepsi kemudahan menggunakan) SIMDA diuji melalui Hipotesis H8. Hasil Pengujian H8 diterima, yang menunjukkan bahwa konstruk keinovatifan personal berpengaruh terhadap kemudahan penggunaan persepsian (persepsi kemudahan menggunakan) SIMDA dalam pekerjaan sehari-hari. Hasil pengujian menunjukkan bahwa keinovatifan personal 
berpengaruh positif terhadap kemudahan menggunakan persepsian, ini berarti Semakin tinggi keinovatifan pengelola keuangan Pemerintah Kota Batu terhadap teknologi yang digunakannya semakin tinggi pula persepsi kemudahan untuk menggunakan SIMDA dalam pekerjaannya.

Pengaruh konstruk kegunaan persepsian terhadap keberterimaan diuji melalui Hipotesis H9. Hasil pengujian menunjukkan bahwa H9 diterima dalam penelitian ini yang menunjukkan bahwa kegunaan persepsian memiliki pengaruh terhadap keberterimaan menggunakan SIMDA di dalam pekerjaannya sehari-hari. Hasil pengujian menunjukkan bahwa kegunaan persepsian berpengaruh positif terhadap keberterimaan SIMDA. Temuan ini sesuai temuan pada umumnya penelitian penerimaan teknologi, konstruk kegunaan persepsian sering menunjukkan pengaruh yang paling kuat terhadap perilaku keberterimaan sistem informasi. Dalam model penelitian ini, konstruk kegunaan persepsian merupakan yang paling kuat memengaruhi keberterimaan SIMDA secara langsung. Hal ini menunjukkan bahwa semakin tinggi persepsi pengelola keuangan Kota Batu terhadap manfaat SIMDA yang digunakannya di dalam bekerja, akan mampu meningkatkan keberterimaan penggunaannya untuk terus melanjutkan penggunaan SIMDA tersebut. Hasil penelitian ini mendukung teori TAM yang dibangun oleh Davis (1989), serta mendukung kebanyakan temuan peneliti sebelumnya. Temuan ini selaras dengan temuan dari beberapa penelitian seperti Algahtani (2001), Mather et al. (2002), Tangke. (2004), Rouibah dan Hamdi (2009), Widodo (2012), Bavarsad dan Mennatyan (2013), Shipps dan Phillips (2013), dan Leksono (2015), menunjukkan bahwa konstruk kegunaan persepsian berpengaruh terhadap keberterimaan implementasi sistem informasi.

Pengaruh konstruk kemudahan penggunaan persepsian terhadap kegunaan persepsian (persepsi manfaat) SIMDA diuji melalui Hipotesis H10. Hasil Pengujian menunjukkan bahwa H10 diterima dalam penelitian ini yang menunjukkan bahwa kemudahan persepsian memiliki pengaruh terhadap kegunaan persepsian (persepsi manfaat) menggunakan SIMDA di dalam pekerjaannya sehari-hari. Hasil pengujian menunjukkan bahwa Kemudahan penggunaan persepsian berpengaruh positif terhadap persepsi manfaat SIMDA. Temuan ini sesuai temuan pada umumnya penelitian penerimaan teknologi, konstruk kegunaan persepsian sering menunjukkan pengaruh yang paling kuat terhadap kegunaan persepsian (persepsi manfaat) sistem informasi. Dalam Model penelitian ini, konstruk kegunaan persepsian merupakan yang paling kuat memengaruhi kegunaan persepsian (persepsi manfaat) SIMDA. Hal ini mengindikasikan semakin yakin pengelola keuangan di SKPD 
Pemerintah Kota Batu bahwa SIMDA yang digunakan dalam pekerjaannya adalah mudah digunakan, maka persepsi terhadap manfaat menggunakan SIMDA akan semakin meningkat.

Pengaruh konstruk kemudahan penggunaan persepsian terhadap keberterimaan SIMDA diuji melalui Hipotesis H11. Hasil pengujian menunjukkan bahwa H11 diterima dalam penelitian ini yang menunjukkan bahwa kemudahan persepsian memiliki pengaruh terhadap keberterimaan menggunakan SIMDA di Pemkot Batu. Hasil pengujian menunjukkan bahwa kemudahan pengunaan persepsian berpengaruh positif terhadap keberterimaan SIMDA, ini berarti semakin yakin pengelola keuangan di Pemkot Batu bahwa SIMDA yang digunakan dalam pekerjaannya adalah mudah digunakan, maka keberterimaan implementasi SIMDA tersebut juga akan semakin meningkat.

Hasil perhitungan Sobel Test dilakukan dengan menggunakan software Microsoft Excel 2010 dengan hasil seperti terlihat dalam Tabel 4 dibawah ini.

Tabel 4. Hasil pengujian Sobel Test

\begin{tabular}{lllllllll}
\hline Konstruk & A & B & c & a.b & Sa & Sb & Sab & Tab \\
\hline KP -> PEU -> PU & 0,07952 & 0,34161 & 0.15677 & 0,02716 & 0,03634 & 0,06998 & 0,013839 & 1,96288 \\
PEU -> PU-> SA & 0,34161 & 0,53597 & 0.29299 & 0.18309 & 0,6998 & 0,04769 & 0,041028 & 4,46247 \\
\hline
\end{tabular}

Hipotesis $12\left(\mathrm{H}_{12}\right)$ menyatakan bahwa kemudahan penggunaan persepsian memediasi antara keinovatifan personal terhadap konstruk kegunaan persepsian. Berdasarkan hasil pengujian seperti terlihat pada Tabel 3 diatas, didapatkan hasil perhitungan Sobel Test nilai T statistik 1,96288 (>1,64). Nilai koefisien jalur efek mediasi (a.b) 0,027166 lebih kecil dari koefisien jalur pengaruh utama $(c)$ 0.15677, hasil tersebut menunjukkan bahwa konstruk kemudahan penggunaan persepsian memediasi sebagian (partial mediation) antara konstruk keinovatifan personal terhadap konstruk kegunaan persepsian. Hasil temuan ini membuktikan bahwa keinovatifan personal memiliki hubungan tidak langsung terhadap kegunaan persepsian dengan kemudahan penggunaan persepsiian menjadi variabel perantaranya. Kegunaan implementasi SIMDA juga dipengaruhi oleh faktor individual yaitu keinovatifan personal dalam menggunakan SIMDA tersebut. Dengan adanya bukti bahwa persepsi kemudahan memediasi sebagian dalam hubungan antara keinovatifan personal terhadap kegunaan persepsian, hal ini berarti meskipun seseorang akan menganggap dirinya mempunyai keinovatifan dibidang sistem informasi, akan tetapi sikapnya terhadap sistem tersebut juga akan dipengaruhi oleh bagaimana orang tersebut menilai apakah sistem tersebut mudah digunakan. Setiap individu pengguna SIMDA mempunyai keinovatifan yang 
berbeda-beda, Tentunya tidak semuanya memahami dengan mudah aplikasi SIMDA yang digunakan.

Hipotesis $13\left(\mathrm{H}_{13}\right)$ menyatakan bahwa kegunaan persepsian memediasi antara kemudahan penggunaan persepsian terhadap konstruk keberterimaan SIMDA. Berdasarkan hasil pengujian seperti terlihat pada Tabel 3 diatas, didapatkan hasil perhitungan Sobel Test nilai T statistik 4,46247 (>1,64). Nilai koefisien jalur efek mediasi (a.b) 0,18309 lebih kecil dari koefisien jalur pengaruh utama (c) 0.29299, hasil tersebut menunjukkan bahwa konstruk kegunaan persepsian memediasi sebagian (partial mediation) antara kemudahan penggunaan persepsian terhadap konstruk keberterimaan SIMDA. Hasil temuan ini membuktikan bahwa persepsi kemudahan memiliki hubungan tidak langsung terhadap keberterimaan implementasi SIMDA dengan persepsi kegunaan menjadi variabel perantaranya. Dengan demikian, kegunaan persepsian dikatakan memediasi sebagaian (partial mediation) pengaruh kemudahan penggunaan persepsian terhadap keberterimaan implementasi SIMDA. Keberhasilan implementasi sistem baru akan sangat didukung oleh bagaimana sikap pengguna sistem dalam menerima implementasi sistem tersebut. Sikap menerima dan puas dengan pemanfaatan sistem baru itu sendiri, terbukti sangat dipengaruhi oleh bagaimana persepsi pengguna terhadap kemudahan dan kegunaannya. Dengan adanya bukti bahwa persepsi kegunaan menjadi pemediasi parsial dalam hubungan antara persepsi kemudahan terhadap keberterimaan implementasi SIMDA, menunjukkan bahwa tidak semua pengguna yang merasakan kemudahan penggunaan SIMDA mempunyai persepsi tentang manfaat SIMDA, tetapi mereka sudah menerima implementasi SIMDA disebabkan oleh mudahnya mengoperasikannya.

Teori Technology Acceptance Model (TAM) yang dikembangkan oleh Davis (1989) menunjukkan adanya hubungan yang kuat antara persepsi kemudahan penggunaan, persepsi kegunaan dan keberterimaan. Dalam TAM, keberterimaan yang diwujudkan dengan minat menggunakan teknologi atau sistem informasi baru, dipengaruhi oleh dua faktor utama yaitu persepsi kemudahan penggunaan dan persepsi kegunaan serta adanya pengaruh persepsi kemudahan penggunaan terhadap persepsi kegunaan. Hasil penelitian ini secara empiris membuktikan teori TAM bahwa persepsi kemudahan penggunaan SIMDA akan mempengaruhi persepsi kegunaannya serta tingkat keberterimaan pengelola keuangan Pemkot Batu terhadap implementasi SIMDA.

\section{Model Hasil Penelitian}

Gambar 2 di bawah menyajikan model hasil penelitian ini, penerimaan pengguna terhadap implementasi SIMDA berbasis akrual di Pemkot Batu dilihat melalui 
keberterimaanya penggunaan SIMDA. Pengguna SIMDA lebih berminat pada sistem informasi tersebut berguna bagi pekerjaan mereka serta sesuai dengan kebutuhan pekerjaan mereka sehari-hari. Pengguna akan berminat untuk menggunakan atau terus menggunakan SIMDA apabila mereka meyakini bahwa SIMDA berguna bagi mereka dalam menangani pekerjaan mereka sehari-hari. Kebermanfaatan SIMDA tidak terlepas dari faktor institusional berupa dorongan dan komitmen dari manajemen untuk mendorong dan menghargai upaya para pengelola keuangan didalam menggunakan SIMDA. Adanya pengaruh sosial dari pimpinan dan rekan kerja yang memberikan saran dan pendapat tentang kebermanfaatan SIMDA juga ikut membantu pemahaman kepada para pengelola keuangan tentang kegunaan SIMDA didalam membantu tugas-tugas mereka. Keyakinan manfaat menggunakan SIMDA juga tidak terlepas dari faktor teknologi, pengaruh faktor teknologi berupa kualitas informasi yang dihasilkan oleh SIMDA dan kualitas sitem dari SIMDA. Apabila Kualitas informasi dan kualitas sitem baik dan sesuai dengan kebutuhan, maka pengelola keuangan akan merasakan manfaat dari penggunaan SIMDA. Selain itu juga faktor individual pengguna berupa keinovatifan personal, individu yang inovatif mau mencoba menggunakan teknologi baru maka akan lebih cepat beradaptasi dan mengetahui manfaat dari teknologi tersebut.

Pengguna SIMDA akan menerima implementasi SIMDA apabila mereka yakin bahwa SIMDA tersebut mudah digunakan, dipahami dan tidak mengalami kesulitan dalam menggunakannya. Kemudahan menggunakan SIMDA tidak terlepas dari faktor individual. Individu yang mempunyai kemampuan diri tentang penggunaan komputer dan individu yang mempunyai keinovatifan untuk terus menggunakan SIMDA akan meningkatkan persepsi bahwa SIMDA yang digunakan itu mudah digunakan dan dipahami.

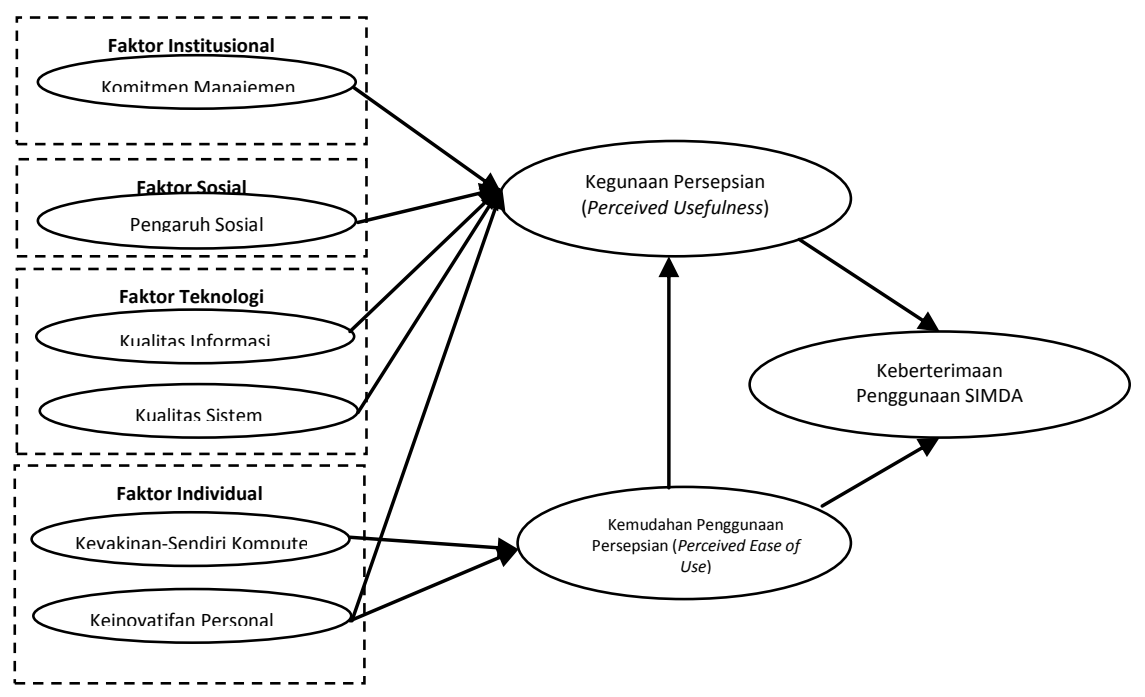

Gambar 2. Model Hasil Penelitian 


\section{SIMPULAN}

Penelitian ini menemukan bahwa pengelola keuangan yang menggunakan SIMDA berbasis akrual di Pemkot Batu Provinsi Jawa Timur dapat menerima implementasi SIMDA yang digunakan di kantornya. Hal ini dapat diketahui dari sebagian besar pengguna merasa puas dan secara keseluruhan setuju atas penggunaan SIMDA di kantornya. Penerimaan yang baik terhadap implementasi SIMDA di Pemkot Batu akan mampu memberikan manfaat dalam meningkatkan efektifitas dan efisiensi pengelolaan keuangan sehari-hari. Tingkat Penerimaan dari pengguna di Pemkot Batu masih dapat ditingkatkan lagi dengan cara memengaruhi hal-hal yang dianggap penting oleh pengguna.

Keberterimaan implementasi SIMDA dapat dilihat dari: pertama, persepsi kemanfaatan dari SIMDA, bahwa pengelola keuangan sebagaian besar setuju SIMDA dapat membantu pekerjaanya dengan cepat, dapat meningkatkan kinerja, produktifitas, dan efektifitasnya. Kedua, sebagian besar pengelola keuangan pengguna SIMDA beranggapan bahwa SIMDA mudah digunakan sehingga tidak menyulitkan untuk menggunakannya. Ketiga, pengelola keuangan merasa puas dan setuju dengan implementasi SIMDA.

Penelitian ini membuktikan secara empiris bahwa komitmen manajemen, pengaruh sosial, kualias informasi, kualitas sistem, keyakinan-sendiri komputer,dan keinovatifan personal berpengaruh terhadap keberterimaan implementasi SIMDA. Tetapi penelitian ini tidak menemukan bukti empiris bahwa keyakinan-sendiri mempengaruhi persepsi kemanfaatan SIMDA (kegunaan persepsian). Hal ini menunjukkan bahwa Pengguna SIMDA lebih mementingkan adanya Faktor komitmen manajemen, pengaruh sosial, kualias informasi, kualitas sistem, keyakinan-sendiri komputer, dan keinovatifan personal dalam menentukan keberterimaan penggunaan SIMDA berbasis akrual di dalam membantu pekerjaannya.

Penelitian ini memiliki beberapa keterbatasan. Pertama, Saat penelitian implementasi SIMDA berbasis akrual masih terdapat beberapa akun pendapatan yang tidak dapat masuk kedalam jurnal akrual sehingga tidak keluar pada laporan akrual. Penelitian selanjutnya disarankan melakukan penelitian kembali apabila sudah dikeluarkan versi terbaru dari SIMDA berbasis akrual BPKP, yang mungkin akan menghasilkan temuan yang berbeda.

Kedua, Hasil analisis model struktural penelitian ini, berdasarkan pada nilai R Square pada Tabel 2 menunjukkan bahwa variabel yang digunakan dalam peneltian ini yaitu konstruk komitmen manajemen, pengaruh sosial, kualitas informasi, kualitas sistem, keyakinan-sendiri komputer, keinovatifan personal, dan kemudahan penggunaan persepsian hanya dapat menjelaskan varian perubahan kegunaan persepsian sebesar 51\%, sementara 
sisanya $49 \%$ dipengaruhi oleh konstruk lain yang tidak tercakup dalam penelitian ini. Begitu juga dengan konstruk keyakinan-sendiri komputer dan keinovatifan personal hanya dapat menjelaskan varian perubahan konstruk kemudahan penggunaan persepsian sebesar 54,6\%. , Penelitian selanjutnya diharapkan dapat mengajukan model dengan konstruk independen yang lebih mampu menjelaskan konstruk dependen, seperti konstruk dari model UTAUT yang merupakan gabungan dari model-model dan teori penerimaan teknologi. Beberapa variabel UTAUT antara lain: ekspektasi kerja, ekspektasi usaha, kondisi-kondisi yang memfasilitasi dan juga menggunakan variabel moderasi, seperti gender, umur dan pengalaman kerja.

\section{DAFTAR PUSTAKA}

Agarwal, R \& Prasad, J. (1999). Are Individual Differences Germane to the Acceptance of New Information Technologies? Decision Sciences Vol 30 No. 2

Ajzen, I. (1991). The Theory of Planned Behavior. Organizational Behavior and Human Decision Processes 50, pp 179-211

Algahtani, S. S. (2001). "The Applicability of TAM Outside North America: An Empirical Test in the United Kingdom". Information Resources Management Journal. Vol. 14 , No. 3, pp. 37

Armstrong, B., Fogarty, G.J., Digsdag, D., \& Dimbleby, J. (2005). Validation of a computer user satisfaction questionnaire to measure IS success in small business. Journal of Research and Practice in Information Technology, vol. 37, no. 1, pp. 27 - 42

Bailey, J. E., \& Pearson, S. W. (1983). Development of a Tool for Measuring and Analyzing Computer User Satisfaction. Management Science, Vol. 29, No. 5, pp. 530-545

Bandura, A. (1977). "Self-Efficacy: Toward a Unifying Theory of Behavioral Change," Psychological Review. Vol. 84, No. 2, pp. 191-215.

Baridwan, Z. (2012). Analisis Keperilakuan Individu Terhadap Implementasi Sistem Informasi Akuntansi: Model penerimaan dan Kesuksesan Sistem Informasi berbasis Teknologi. Disertasi tidak dipublikasikan, Universitas Brawijaya, Malang

Bavarsad, B., \& Mennatyan, M. A. (2013). A Study of the Effects of Technology Acceptance Factors on Users' Satisfaction of E-Government Services. World Applied Programming. Vol. 3, No.5, pp 190-199

Compeau, D. R., \& Higgins, C. A. (1995b). Computer self-efficacy: development of a measure and initial test. MIS Quarterly.Vol. 19, No. 2, pp. 189-211.

Dai, C. Y., Kao, M. T., Harn, C. T., Yuan, Y. H., \& Chen, W. F. (2011). The researh on User Satisfaction of Easy Teaching Web of Taipei Assessed via Information Quality, System Quality, and Technology Acceptance Model. The $6^{\text {th }}$ International Conference on Computer Science \& Education, pp 758-762.

Dalcher, I \& Shine, J. (2003). Extending the New Technology Acceptance Model to Measure the End User Information Systems Satisfaction in a Mandatory Environment: A Bank's Treasury, Technology Analysis \& Strategic Management. Vol. 15, No. 4, pp. 441-455.

Davis, F. D. (1989). Perceived Usefulness, Perceived Ease of Use, and User Acceptance of Information Technology. MIS Quarterly, Vol. 13, No. 3, pp. 319 - 340.

DeLone, W. H., E. R. McLean. (1992). Information systems success: The questfor the dependentvariable. Inform. Systems Res. Vol. 3, No.1, pp. 60-95. 
DeLone, W. H. dan McLean, E. R. (2003). The DeLone and McLean Model of Information Systems Success: A Ten-Year Update. Journal of Management Information Systems. Vol. 19, No. 4, pp. 9-30

Fulk, J. (1993). Social Construction of Communication Technology. Academy of Management Journal. Vol. 36, No. 5, pp. 921-950

Jogiyanto. (2007). Model kesuksesan Sistem Informasi. Yogyakarta: CV Andi Offset.

Jogiyanto. (2008). Sistem Informasi Keperilakuan Edisi Revisi. Yogyakarta: CV. Andi Offset.

Jogiyanto. (2008). Metodologi Penelitian Sistem Informasi.Yogyakarta: CV. Andi Offset

Lai, C. S. A., \& Pires, G. (2010). Testing of a Model Evaluating e-Government Portal Acceptance and Satisfaction.The Electronic Journal Information Systems Evaluation. Vol. 13, pp. $35-46$

Leksono, A. B. (2015). Keberterimaan Implementasi SPAN dan SAKTI Studi Pada satuan kerja Wilayah Pembayaran KPPN Masohi. Tesis tidak dipublikasikan, Universitas Brawijaya, Malang

Lewis, W., Agarwal.R, \& Sambaburthy, V. (2003). Sources of influence on beliefs about information technology use: an empirical study of knowledge workers. MIS Quarterly. Vol. 27, No. 4: pp. 657-678

Lin, J. C., \& Lu, H. (2000). Towards an understanding of the behavioral intention to use a Web Site. International Journal of Information Management, V.20, pp. 197-208.

Liu, C., \& Arnet, K.P. (2000). Exploring the Factors Associated with Site Success in the

Mather, D., Caputi, P., \& Jayasuriya, R. (2002). "Is the technology acceptance model a valid model of user satisfaction of information technology in environments where usage is mandatory?". In A. Wenn, M. McGrath \& F. Burstein (Eds.), Enabling organisations and society through information systems (pp. 1241-1250). Victoria University, australia: ACIS 2002 School of Information Systems.

Miyamoto, M., kudo, S., \& Lizuko, K. (2012). Measuring ERP Success: Integrated Model of User Satisfaction and Technology Acceptance; An Empirical Study in Japan. International Conference on Business, Management \& Governance, Vol. 57, No. 16, pp 86-91

Ong, C. S., Day, M. Y., \& Hsu, W. L. (2009). The Measurment of User Satisfaction With Question answering Systems. Information \& Management, Vol.46, pp 397-403

Orlikowski, W. J. (1992). The Duality of Technology: rethingking the Concept of Technology in Organizations. System Researh. Vol. 2, No. 3, pp. 398-427

Rogers, E. M. (1995). Diffusion of Innovations (3th ed.). Free Press, New York

Rouibah, M. (2009). Factors Affecting Information Communication Technologies Usage and Satisfaction: Perspective from Instant Messaging in Kuwait. International Jurnal of Global Information Management. Vol. 17, pp 1-29

Schmitz, J., \& Fulk, J. (1991). Organizational Colleagues, Media Richness, and Electronic Mail: A Test of the Social Influence Model of Technology Use. Communication Research. Vol.18, No.4, pp. 487-523.

Utama, A. (2007). Pengaruh faktor institusional, faktor sosial, serta faktor individu terhadap keyakinan manfaat teknologi informasi dan sikap serta nia menggunakan teknologi informasi. Jurusan Manajemen Fakultas Ekonomu UPN-Yogyakarta

Venkatesh, V., \& Davis, F. D. (2000). A Theoretical Extension of the Technology Acceptance Model: Four Longitudinal Field Studies. Management Science, Vol. 46, No. 2 (Feb., 2000), pp. 186-204

Wibowo, Arief. (2006). Kajian Tentang perliku pengguna Sistem Informasi dengan PendekatanTechnology Acceptance Model (TAM). Program Studi Sistem Informasi Universitas Budi Luhur Jakarta. 
Yusof, Y. M., Kuljis, J., Anastasia P., \& Stergioulas, L. K. (2008). An Evaluation Framework for Health Information Systems: Human, Organization and Technology-Fit Factor (HOT-Fit). International Journal of Medical Informatics. Vol. 77, pp 386-398.

Yoon, Y., Guimaraes, T., \& O'Neal, Q. (1995). Exploring the Factors Associated with expert system Suceess. Mis Quarterly, Vol. 19, No. 1, pp. 83-106

Zmud, R.W. (1984). Examination of Push-Pull Theory Applied to Process Innovation in Knowledge Work. Management Science. Vol. 30, No. 6, pp. 727-738 